\title{
Niqab Between Texts and Fashion Trend
}

\author{
Ala'i Nadjib \\ \{alai.nadjib@uinjkt.ac.id\} \\ Universitas Islam Negeri Syarif Hidayatullah Jakarta, Indonesia
}

\begin{abstract}
Today, niqab has become a discussion everywhere due to various internal and external factors. Niqab according to Cambridge Dictionary is a piece of cloth worn by some Muslim women to cover the whole face except the eyes. It was popular before Islam came. The Prophet did not forbid using it nor recommended it. A number of Islamic law experts have different opinions about niqab. In its development, niqab has different functions, some tends to be religious some to be simply dress and make up and other to hide from men's gaze. The goal of wearing niqab is not even personal decision but institutional policy too. From that reasoning we know that using niqab is not single entities, because it has different backgrounds too. This paper is an elaboration of developing texts about niqab, the experience of its users and market trends or fashion models that make niqab performance in Indonesia different from the general. This is where the value of religiosity, consumerism and freedem express of dress. But does anyone benefit from this smelter? including the cultural and social political situation that surrounds it. The method on this research is descriptive qualitative. To get depth information, the writer interviewed women' students of UIN Syarif Hidayatullah Jakarta and the female ulama of Pesantren (Islamic Boarding School).
\end{abstract}

Keywords: niqab, women, Islamic text, Islamic scholars and fashion

\section{Introduction}

This paper will discuss the niqab, both in Islamic texts and in the perspective of fashion in Indonesia. Why? because in its development, niqab is not considered merely as a cover for aurat (for those who agree the opinion that mandatory must also be covered) but also has become part of the fashion industry.

To analyze the different thoughts of the text the writer also interviewed a number of UIN students and Ibu Nyai (female ulama) and their students who used the niqab as well. The interesting in Indonesia about niqab is that it is colourfull and beautyfull accessories. Some of them using masker to cover their face as a beginner before they decide to wear niqab. So niqab in Indonesia is much different with Saudi or others Arabic Country.

\section{Islamic View of the Niqab}

Like aurat and veil, the niqab actually also has many interpretations. Aurat is an Islamic term that symbolizes a division of limbs, either men or women, who are illegally opened or exhibited. In other words, a limb that must be closed and hidden and haram non-mahram see 
it. Covering aurat is obligatory on every Muslim, regardless of men or women. The obligation of covering the aurat is based on the arguments of the Quran, the Hadith and explored by fiqh Actually there is no single verse of the Quran that explains the use of niqabs. The Quranic verse that is often referred to is the covering of aurat is the surah of an-Nur; verse 31. For example the word illa maa zhahara minh [1], is defined as except what appears (ordinary) from it. the verse is then continued with the next verse which means let them cover with veil to their chest [2]. Covering the face is not discussed in the verse which is usually a reference in giving a definition of aurat.

Women's aurat can be seen from two situations [3] : the aurat in the prayer, the aurat in front of ajnabi men (men who may marry him) and aurat while with their mahram, A mahram is an unmarriageable kin with whom marriage or sexual intercourse would be considered haram, illegal in Islam . Although there are exceptions from the Islamic scholars (madzhab) to also cover the face outside prayer with some reasoning. With various discussions in the verses in the Quran, it is almost certain that there is no verse in the Quran discuss about niqab. The hadith narrated from Umm Khalad and ijtihad of the ulama fiqih is the one that has been the argument if needed [4]. Mahmud Hamdi Zaqzuq in the book An-Niqab 'Adat Laisal Ibadah (Niqab is Culture not worship) explains how and the origin of the wearing of niqabs in the Arabic tradition. One of the opinions in the book came from Abu Syuqqah the Muslim Brotherhood leader who wrote his argument on niqab. In his paper in the book, An_Niqab Fi Syariat al-Islam said that the niqab was one of the clothes worn by women since the time of jahiliyah (pre Islamic era) and continued until they embraced Islam. The Prophet did not make the niqab a problem. But also does not make a new law by obliging, advocating or calling for it to become niqab is sunnah. The obligation only falls on the wife of the Prophet's wife (ummahat almukminin) who is devoted. They must cover all their limbs and face when they come out of the house not only the hijab that covers the head and chest [5].

It is said that one day Aisha disguised herself in a niqab and slipped into the Ansor crowd of women. At that time they wanted to welcome and preach the marriage of the prophet to the beautiful Shafiyah binti Huyay, Shafiyyah bin Huyyah is one of the most beautiful wives of the prophet Muhammad. She is decadent of Jew But the Messenger of Allah apparently recognized from the eyeball that it appeared between Aisha's niqab. Aiysah actually wanted to welcome Shafiyah too. Aisha turned away and walked hurriedly, so that the Messenger of Allah followed him. This story is recorded in the hadith of Ibn Majah and Abdullah bin Umar [6]. In this case we see that the niqab becomes tanakkur (hiding). Maybe Aisha did not or had not been invited in welcoming the new wife of the prophet, but she was curious.

By looking at the argument, we see that the niqab is already in the Arabic tradition, but the word tanakkur in the hadith is interpreted as an attempt to hide itself. Means the niqab is an addition to clothes other than hijab that is not commonly worn. The reality here is also confirmed that the Muhammad prophet never required women to wear it. Meanwhile, ulama fiqih agreement (qiyas) decide that the niqab is not obligatory.) Even Imam Malik said, using a niqab is an excessive attitude in religion. Another argument come from who adheres to Imam Shafi'i, that covering the face and the hands in front of men who are not mahram is mandatory). Thus, wearing or not wearing it does not completely contradict the Shari'a. Unless there is slander or segregation. At the moment, women are not supposed to suppress their niqabs if they create an inclusive situation. If there is a situation like this, then the benefit is certainly preferred. On the contrary, with the application of the niqab above, prohibiting its use also does not conflict with the Shari'a. And especially Muslims should not deny what is still disputed by scholars. The niqab is not a matter of principle (ushul) in Islam. If its existence actually causes stigmatization, it should be avoided or not wearing the niqab. 


\section{Dilemma of the Niqab Between Prohibition and Freedom of Human Rights}

Today, the use of niqabs is no longer only in the countries of Middle East. In this era of globalization, where migration has erased distance, human encounters and culture are so close. This reality led to the growth of a new culture as acculturation between one region visited by immigrants and their origin countries. And it cannot be avoided that this is also the impact of events in political events in Arabia, such as what they call the Arab Spring. Although it can be seen that those political asylum seekers have been there before where they came from various continents and mingled with the community. The niqab is of course only one form of expression for cultural acculturation. But because it covers the face, its existence raises polemic. Something that is closed can lead to subjective presuppositions, because the face is indeed an identity. For example, in the midst of the progress of civilization in developed countries, there are forms of restraint, oppression, limitation of women's freedom to express their potential. The niqab is also prone to being used by female bombers by hiding explosives behind the hijab they wear and also other irregularities. The incident at the Surabaya church bombing (2018) was carried out by niqabed bombers [7]. Abroad, especially European countries, the ban is also in line with the spread of terror in public places by those who claim to be Muslim groups (extremists). There is an assumption that those with niqabs are part of the terrorist. When the freedom is expression of human rights, so using the niqab user is right. But it can not be generalized as a right. Because niqab is related to many contexts. This then makes decision makers ban the niqab often considering its suitability in that context. The Yogyakarta UIN Chancellor, who has more than 42 students in niqabs, had issued a ban on wearing niqab with some arguments for his institution that may public do not know. Unfortunately this ban was revoked.

There are several countries for various reasons ban the niqab. France was the first country in Europe to use niqabs in 2010. This ban was also strengthened by the decision of Human Rights Court. But the court warned that this ban could cause stereotypes and excessive. Thariq Ramadhan, grandson of founder Hasan Al-Banna who lives in France argued that given the increasing number of Muslims in Europe. There is a need to establish a Muslim identity in the West to avoid reactive processes. That is, there is a necessity to consider Islamic teachings and the European environment to hold a complete reflection on issues that are very sensitive about faith, psychology, emotional education and culture. Whether they are individuals or communities. Everything is to minimize the West's reactive attitude towards Muslims for a clearer and more convincing future [8].

France also not only prohibits the niqab but also the burkini. Manuel Valls French Prime Minister at the time said that public space must be free from religious life. Burkini is a symbol of oppression against women. According to him, women who cover their bodies (niqabs and burkini) give rise to the perception that women are dirty and must be covered. It does not match the value of the French nation. In addition France, there are Belgium, Czech Austria, Germany, Italy, Spain, Switzerland, Netherlands and more. Even though the supreme court stated that there was no paying the law for the prohibition of niqabs, but the conservative politicians called for them not to use the niqab because it disrupted interaction as interaction with the Austrian Majority Catholic population. Such inconvenience is also felt, for example when those who wear the niqab are dealing with public services and hamper relationships with clients. Germany as a conservative, has an different opinion with France about niqab . According to German Chancellor, Angela Merkel wants a ban on the niqab is only applied to certain conditions. But their coalition, the Social Democratic Party, opposed the idea. While his Minister of Internal Affairs, Thomas de Maizere said that the niqab was not properly worn in Germany, it was difficult to ban it nationally. And again because the face is a public identity, niqabs make it difficult in the relations of social relations and public services and he may be considered a threat and an increase in radicalism and suicide bombings. Merkel also reminded that those with niqabs barely had a chance to mingle. The polemic of niqab s do cover many countries in Europe. Not only Germany but also countries like the Netherlands and Italy. A very new decision, enacted by Denmark as of May 31 2018. Denmark decides that the 
use of niqabs in all regions is illegal and that those who use them will subject to sanctions. According to state authorities, the regulation was taken not to target certain religions but to define the niqab, as part of the prohibition to cover the face with little visible eyes like the shape of a niqab in a public place. Closing the face is only allowed in places that are very special such as conditions or weather that is very cold and when driving with a helmet. The person who violates will get a fine of 1000 corn or equivalent to 118 pounds.

The Director of Amnesty International, Gauri Van Gulik, strongly criticized the ban on niqab. He argued that all women should be given the freedom to express their clothes according to their identity or trust. If this prohibition is for public security, it can be legitimized, but if the ban on using it as a whole is clearly discriminated against and violates women's freedom [9].

Because it turns out the niqab is very contextual and deals with the reality of heterogeneous reality. What cannot be prohibited absolutely or one hundred percent is allowed. But it can be concluded that almost. Everything that prohibits is because the face is an identity and because of that, it must be shown. Indonesia also experienced almost the same thing with niqab. In educational institutions, both formal like schools or universities and Islamic boarding schools (Pesantren) that they have their own rules. Sunan Kalijaga State Islamic University, Yogyakarta, for example on March 5, 2018, made an official letter to ban students from using niqab and they would be trained to follow the formal academic regulation. Of course this caused a pro and contra reaction until finally a few days later, this ban was revoked. There are those who forbids and someone obliges. The Ath Tholibiyah Tegal Vocational School for example requires students to use a niqab. According to its administrator, Habib Sholeh, this obligatory niqab had nothing to do with radicalism which people feared. The school still maintains nationalism and love for Indonesia. Every Monday they hold a flag ceremony and the foundation has Ahlussunnah wal jamaah link and family members with Nahdlatul Ulama backgrounds. The niqab is only intended for students not to fall into promiscuity and disobedience.However, this obligation is considered to have violated the Ministry of Education and Culture Regulation No.45 of 2014. and asks schools to evaluate. Why because in the learning process students are not allowed to close their faces. If inside the pesantren and outside school, please. Moreover, this vocational school has separated female students and male students in the teaching process. Finally the school agreed on this middle ground.

There is also a pesantren which requires the wearing of niqabs for its students, namely Pondok Pesantren (Islamic Boarding) Ali Ba'alawi Kencong Jember East Java. Their female santri (female students) obligate to using niqab and gamis. But the obligation to niqab is only in the area of the pesantren because if they return to their homes, it is beyond their authority. As my interview to The result interview with Young Female Ulama (N) and sister of Ali Ba'lawi. She is thes sisiter of the Pesantren (Islamic School) Opposite to Pesantren Ba'alawi and SMK At Tholabiyah, The pesantren Darussunnah that locates behind the UIN II campus forbids students from wearing a niqab in the Pondok's area. Most of the santri pesantren who have Ma'had Ali are students of UIN. Almost like students at At Tholabiyah Tegal, students will usually use and remove the niqab outside the location of the pesantren.

\section{Experience of women using the Niqab}

When banning niqabs occurs in European countries on other continents. The reaction would have been widespread, it also happened on the first day in Denmark, persistent resistance was mainly from women. But as usual because women are not single entities, actually wearing a niqab also does not have a single motivation or reasoning. There are even those who don't know the reason, she feels protected. Another woman young cleric ( Ibu Nyai) she decided to use her own niqab, after marriage not under pressure or coercion. She understands that niqab in fiqh (Islamic law) is mere khilafiyah (debatable). So she suggest does not over to encourage or prohibit it. Because of that she does not always close her face in front of the brothers who are not muhrim or to the elderly, she said it was for taaduban (reverence). The niqab is actually NU tradision, but now because there is a problem of terrorism and radical groups and some fact has relates to women who are using the niqab, niqab is often misunderstood. According to her, using niqab when outside is feeling safe. Even though she decides for using niqab, she open a face sometime, for instan when she meet elder who still has family ties. She argues that it is a matter of taaduban not consistency in the view that the face is a aurat outside the conception of 
aurat in prayer[10]. Two of the three students I interviewed said that the reason for using the niqab was for security reasons. The experience of being harassed by a man by touching their body is deliberately experienced since high school. Only one female students that tshe worn niqab is following Hanafi's scholar and because she studies with men (co education), so using niqab is a must.

It is necessary to have a thorough research and represent a group of women if we want to analyze and see the motivation for wearing the niqab. There are groups that are very conscious of using it as an ideological choice. Some want to hide their identity, make it a symbol of resistance or feel safe from sexual harassment or violence so they choose to close. What to watch out for when they meet them and say: "Yes, just want to wear it", it's like a floating period and can be used for certain purposes. Because when she decides to get niqab that's where she has a new identity that is different from most of his friends.

The experience of wearing niqabs was also experienced by Britons (Birmingham Metropolitan College). She is a female geneticist, using the niqab since the age of 14 despite her parents' opposition. According to her, holding a niqab is a personal right to be close to God, the Niqab liberates and makes it dignified and a member of strength. The niqab has made her a human. Moreover, women have the freedom to choose and decide what they wear. People will judge their intelligence and character not because of what they use. The niqab has made her a human being, a simple step.

\section{Niqab and Commodification}

Commodification has been described in various theories. A word taken from the word commodity and meaning goods that have exchange rates. The theory that a person appears so far has been referred to Vincent Mosco [11] If at first the use of niqabs or hijab or headscarves is believed to be a religious practice that carries religious values and is obeyed, then in its development, this value is then captured by the market and becomes a commodity that is rewarding and predicted to profit. This is where commerclization of religion occurs. Usually we have only seen niqabs in the dark colors and abayas. Even now if we go to Arabia, for example, as long as the eye can see, there is only a dark color for its users. If there are various variants, that is only in the eyes, as we see for example in Afghanistan. The eyes are slightly open like in Indonesia or are closed all with fine threaded dressings such as those in Central Asian countries. But about the color, the niqab or burqa there are still in dark material motives. I was upset because when I spent 10 days in Saudi Arabia, as long as my eyes looked at all women using dark colour for their clothes. According to someone who had lived there for decades, the state also intervened in the color of the clothes worn by women. It is not permitted to be bright or motivated because it is feared that it will create a male's lust. I caught in this context, women were asked to participate in guarding men's faith from bad desires. An absurd relationship, because all people actually have to account for their actions and they are of course born with an interest in the opposite sex of each. Not far to the Middle East or immigrants, in the Temboro Magetan Village of East Java, we will almost come across the same scene. In this Temboro village, Pondok Pesantren al-Fatah was established where all students were required to niqab. In reports that can access digital or social media channels that can be accessed and the testimonies of those who have visited Temboro, they also wear black gamis and niqabs. Later the black niqab also happened to be worn by a family of suspected terrorists or those who had an affiliation with the radicalism movement. Of course this can cause trauma to the community in various levels. For example, worry about bringing bombs and so on. Especially after bombing the church in Surabaya several months ago. Diana Nurliana, one of the founders of the Niqab Squad and the niqab designer of KARA niqab brand owner tells that a friend who uses an office elevator is left behind by another passenger with fear. Of course this made her friends nervous and sad, because they are considered harmful to the public. After talking a lot with the niqabers (a term for niqab users), She decided to design and sell niqabs in soft colors. So that the niqab isn't always black, it starts producing and using it on its own even to walk abroad. The first collection that was launched in March 2018 and sold out within 3 hours. Now the niqab is taken in Jakarta Fashion Week. this designer then makes a new brand for colored niqab, with new brand Taqiya.

Not playing, if previously only the color was compromised, then now the model was made to meet the needs of consumers. For example, there are those who don't like niqabs that are almost like headbands, or round. Nurlian has offered in the form of niqab(niqab) 
with pashmina's style, rectangles or instant niqab. Don't ask about the price, because the design of the niqab is made from the Chiffon Burj Emirates material which is very rarely found in Indonesia. Although she can also use other material. All of this is certainly for the convenience of consumers [12]. If we are observant, niqabs are now spread from Papua to Merauke. Even in the small market. How come? That's all because the niqab is a consumer And according to market law there is demand for supply. The niqab, though not specifically designed by famous desianer, looks colorful on display. According to a woman who has a Muslim clothing store and uses niqab; Niqab sales, niqab and jilbab has increased since the last 2 years. She was shopping in Bandung to sell it back in her shop. As with the hijab, we can now see niqabs in various models. According to the price. From the plain black to colorful or with various accessories on the niqab, from the plain to the diplomatic. The niqab with its various models looks like fashion, for example, we can see it from what is worn by the role artist Popy Melati Sukma and now renamed Khadija. So like the hijab /jilbab, the niqab has experienced rapid development and has become a new industry like its brother; hijab Those who decide to niqab also have tutorial facilities. Bridal dress is no less model than conventional ones. In the end for those who decide whether to look niqabed and consider it an obligation, then they will increasingly have a choice of fashion and those who benefit most are business people. When colors are considered part of things that are not suitable for women because they can attract male lust, then Diana Nurliana the designer before deciding to make the niqab colorful, She argues that it's not why colorful origin doesn't overdo it. If this phenomenon continues to be sustainable, it is not impossible that Indonesia will become a niqab industry market that tempts designers to continue to create and take advantage of business opportunities.

\section{Niqab Squad, Niqaber Forum}

If there is a forum that all members use their niqabs, it is the community of the niqab squad. If in the Islamic period the niqab is used as part of hiding the face. So this squad was actually established to be a joint forum and perform publicly in all activities. Like other squads they also exist and do a photo together if there is a meeting. It Founded in February 2017 by niqaber, among them by designers Nurliana, models Indadari and Umi Pipik, this squad has more than 3000 members by the end of 2017 .

Usually they gather on weekends at their respective places and share their or experience, especially story and challenge niqab because the niqab has not become a common thing and is assumed to be a radicalism movement. Until now they continue to seek recognition for their existence in various activities. Sports such as archery, recitation and fundraising for charity, for example for Muslim Rohingnya. They continued to advertise positive images of the niqabed people, including post Surabaya church bombs, among which niqabed women.

\section{Conclusion}

By paying attention to the reality of the text and context above, the niqab is not something that has a single motivation or aspiration. In the Indonesian context, various kinds of communal and personal facts were found in their use. Communal intention is when the niqab is present in groups and we can find it in institutions or institutions. As an example above, the Ath Tolabiyah Foundation requires students or students to get niqabed. The same obligation is also applied in the Ali Ba'alawi Islamic Boarding School. Besides Ba'alawi and Ath Tholabiyah, there was the Al-Fatah Pesantren in Temboro Magetan which was also known as the Madinah village, all of this daughters were niqabed. In these institutions Islamic teaching is taught with values that are commonly practiced and practiced by Indonesian Muslims. They also love the homeland and are far from what is called radical. Although the niqab is also often misused for acts of boundaries that are considered part of the terrorism movement [13]. While the text of the niqab is still debatable and dynamic, recognition of women who use niqabs also varies. Niqab develop rapidly by various mode and color with different brand, price and prestigious. Meanwhile jurisprudence as well as speaking in other aspects of worship shows flexibility by giving the option that sometimes the face must be closed or opened. There is one condition in which to use it is actually excessive. Religion can be concluded in this case that it is not ordered or prohibited from using it. What can actually cause danger and stigma against niqabs is precisely the external factor, namely the development of political movements using religion. For example, as practiced by jihadists and terrorists, to achieve their goals they carry out attacks against those who do not agree with 
their idea and aspiration. This movement was places and share their or experience, especially story and challenge niqab because the niqab has not become a common thing and is assumed to be a radicalism movement. Until now they continue to seek recognition for their existence in various activities. Sports such as archery, recitation and fundraising for charity, for example for Muslim Rohingnya. They continued to advertise positive images of the niqabed people, including post Surabaya church bombs, among which niqabed women.

\section{References}

[1] Quraish Shihab, Tafsir al-Mishbah, Pesan dan Kesan Keserasian Al-Quran.Jakarta: Lentera Hati, 2002

[2] Sahar Amer What is Veiling. NC. University of North Caroline Press. 2014

[3] Abdul Hamid asy-Syarwani, Hasyiyah asy-Syarwani, Bairut-Dar al-Fikr, Juz, II.

[4] Wahid Foundation in Collaboration with UN Women, Hasil Bahtsul Masail. Jakarta, 2018

[5] Mahmud Hamdi Zaqzuq in the book An-Niqab 'Adat Laisal Ibadah. Dar al-Kutub, Mesir. 2008

[6] Al-Hafidz Abi Abdillah Muhammad bin Zayid Al Qazwiyani Sunan Ibnu Majah. Darul Kutub Al Ilmiyyah. Lebanon

[7] https://www.liputan6.com/regional/read/3523607/sebelum-ledakan-bom-surabayasosok- bercadar-masuki-halaman-gki-diponegoro

[8] Thariq Ramadhan, To Be Eupean Muslim: A Study of Islamic Sources (transl), 1999

[9] The Guardian 31 Mei 2018 https:/www.theguardian.com/world/2018/may/31/ denmark-passes-law- banning-burqa-and-niqab

[10] Sahar al-Fifi@saharalfifi in her article The Guardian .co.uk I wear the niqab, let me speak on my own behalf, https://www.independent.co.uk/voices/comment/iwear-the- niqab-let-me-speak-on-my-own-behalf- 882

[11] Vincent Mosco, The Political Economy of Communication: Rethinking and Renewal, (London: Sage Publication, 1996), p. 25 http://www.globalmediajournal.com/open- access/the-political-economy-ofcommunication-second-edition.pdf 4243.html

[12] https://wolipop.detik.com/read/2018/06/07/224320/4058969/1632/desainerini- buktikan-niqab-tetap- laris-walau-pernah-dipakai-teroris

[13] https://internasional.kompas.com/read/2010/12/28/0622226/Wanita.Bercadar.Bunuh. Diri..40.Tewas?page $=$ all. 